\title{
PENGARUH PENDAPTAN ASLI DAERAH DAN DANA PERIMBANGAN TERHADAP BELANJA DAERAH
}

\author{
Nabiyatun Nur Fatimah \\ Anita Nopiyanti \\ Danang Mintoyuwono \\ Universitas Pembangunan Nasional "Veteran" Jakarta \\ nabiyatun@gmail.com
}

\begin{abstract}
This research is a quantitative research that aims to determine the effect of Local Government Revenue and Balancing Fund on Local Expenditure. This research uses data of Local Government Revenue, General Allocation Fund, Special Allocation Fund, and Revenue Sharing Fund of Regency and City in East Java Province as sample. Selection of Regency and City is done randomly after determining acceptable sample amount that is $100 \%$ from all Regency and City in East Java Province. Hypothesis testing in research using Multiple Linear Regression Analysis with SPSS program and 5\% significance level $(0,05)$. The results of the test indicate that the variable of Local Government Revenue and General Allocation Fund have significant influence to the Regional Expenditure. While the variable of Special Allocation Fund and Revenue Sharing Fund have an insignificant effect on Local Expenditure.
\end{abstract}

Keyword : Local Expenditure, Local Government Revenue, General Allocation Fund, Special Allocation Fund, Revenue Sharing Fund

\section{PENDAHULUAN}

\subsection{Latar Belakang Penelitian}

Dengan pesatnya perkembangan masing-masing daerah yang ada di Indonesia, hal tersebut sejalan dengan awal munculnya kebijakan mengenai otonomi daerah dan desentralisasi fiskal. Otonomi daerah menekan adanya peranan serta kemampuan pemerintah daerah dalam pembangunan dan juga pengelolaan keuangan daerah yang diupayakan semakin membaik. Perlunya pemerintah daerah mengubah komposisi belanja yang sebelumnya didominasi untuk penggunaan belanja rutin yang relatif kurang produktif, tetapi mengalokasikan belanja yang mengacu kepada pendanaan atas pengadaan pelayanan umum kepada masyarakat di berbagai sektor, dengan semakin meningkatnya belanja maka akan dibutuhkan dana yang besar agar belanja untuk pemerintah dapat terpenuhi (Sorongan, 2013).

Perkembangan dana alokasi belanja daerah ini ditentukan dengan seberapa besar penerimaan daerah yang bersangkutan. Sesuai dengan salah satu wewenang yang diserahkan kepada pemerintah daerah yaitu wewenang untuk menggali sendiri sumber keuangannya. Pemerintah daerah dapat meningkatkan penerimaan daerah, dimana melalui hasil pengelolaan sumber daya tersebut akan masuk ke dalam penerimaan Pendapatan Asli Daerah (PAD) yang nantinya akan dialokasikan sebagai salah satu sumber pendanaan belanja bagi pemerintah daerah di samping sumber-sumber pendapatan yang lain.

Selain dari Pendapatan Asli Daerah, penerimaan daerah juga bersumber dari dana perimbangan dan lain-lain pendapatan yang sah. Ketika penerimaan pendapatan asli daerah belum mampu untuk memenuhi belanja daerah, pemerintah daerah mengharapkan adanya dana transfer dari pemerintah pusat untuk menutupi dana alokasi belanja daerah setiap tahunnya. Dalam konteks ini, dana perimbangan yang merupakan penerimaan daerah yang ditransfer dari pusat seringkali dijadikan sumber pembiayaan untuk mendanai segala kegiatan setiap harinya. 
Namun pada faktanya ada beberapa daerah yang menyerap anggaran belanja daerah dengan lambat tetapi penerimaan yang mempengaruhi belanja daerah mengalami penurunan. Salah satunya seperti Kota Malang pada tahun 2016 sampai dengan November baru mencapai $64,56 \%$, dari presentase tersebut belanja langsung mencapai Rp498,92 miliar sedangkan belanja tidak langsung yaitu sebesar Rp775,9 miliar.

\subsection{Perumusan Masalah}

Dari latar belakang di atas dapat dirumuskan permasalahan sebagai berikut:

a. Apakah Pendapatan Asli Daerah (PAD) berpengaruh terhadap Belanja Daerah?

b. Apakah Dana Alokasi Umum berpengaruh terhadap Belanja Daerah?

c. Apakah Dana Alokasi Khusus berpengaruh terhadap Belanja Daerah?

d. Apakah Dana Bagi Hasil berpengaruh terhadap Belanja Daerah?

\section{KERANGKA TEORI DAN PENGEMBANGAN HIPOTESIS}

\subsection{Teori Stakeholder}

Menurut Hadi (2014, hlm. 93), menyatakan bahwa Stakeholder adalah seluruh pihak yang berkaitan secara langsung tidak langsung oleh perusahaan, seperti pemerintah, perusahaan pesaing, masyarakat sekitar, lingkungan internasional, lembaga diluar perusahaan (Lembaga Swadaya Masyarakat dan sejenisnya), kaum minoritas dan lain sebagainya, dimana dengan keberadaanya sangat mempengaruhi dan dipengaruhi oleh perusahaan.

Dalam teori ini, masyarakat dan lingkungan sekitar merupakan pemangku kepentingan atau stakeholder inti suatu entitas yang harus diperhatikan. Menurut Lako (2011, hlm. 5), teori stakeholder merupakan suatu ukuran kesuksesan suatu entitas bergantung kepada kemampuan menyeimbangkan beragam kepentingan dari para stakeholder atau pemangku kepentingan.

Sedangkan menurut Rusdianto (2013, hlm. 37) menyatakan bahwa keberhasilan suatu program komunikasi ditentukan oleh perencanaan yang tepat. Sedangkan dalam sebuah program komunikasi yang berdampak tidak bisa disusun dengan mengesampingkan stakeholder yang nantinya akan terkena dampak langsung terhadap program komunikasi.

Berdasarkan uraian di atas dapat disimpulkan bahwa stakeholder adalah pihak berkepentingan yang dapat mengendalikan dan juga mampu mempengaruhi keputusan terhadap pengelolaan sumber-sumber ekonomi agar lebih optimal lagi.

\subsection{Teori Keagenan}

Teori keagenan menyebutkan bahwa perusahaan adalah tempat bagi hubungan kontrak yang terjadi antara manajemen, pemilik, kreditor, dan pemerintah. Teori ini menjelaskan mengenai monitoring berbagai macam biaya dan memaksakan hubungan diantara kelompok ini (Harahap 2011, hlm. 532).

Hubungan keagenan adalah hubungan antara principal dan agen yang di dalamnya agen bertindak atas nama dan untuk kepentingan para principal dan atas tindakannya (action) tersebut agen mendapatkan imbalan tertentu (Suwardjono 2010, hlm. 485).

Namun berbeda dengan pendapat Halim \& Kusufi (2012, hlm. 128) yang menyatakan bahwa teori keagenan yaitu teori yang mengenai hubungan antara prinsipal dengan agen. Dalam konteks teori keagenan tersebut, pemerintah daerah provinsi/kabupaten/kota dapat bertindak sebagai agen maupun sebagai prinsipal.

\subsection{Belanja Daerah}

Belanja daerah dapat dikatakan sebagai suatu kewajiban daerah. Hal ini sesuai dengan UU No. 23 Tahun 2014 tentang Pedoman Pengelolaan Keuangan Daerah, belanja Daerah adalah kewajiban daerah yang diakui sebagai pengurang nilai kekayaan bersih dalam periode tahun anggaran yang bersangkutan 


\subsection{Pendapatan Asli Daerah}

Berdasarkan UU No. 33 Tahun 2004 Tentang Perimbangan Keuangan Antara Pemerintah Pusat Dan Pemerintahan Daerah, pendapatan asli daerah adalah pendapatan yang diperoleh Daerah yang dipungut berdasarkan Peraturan Daerah sesuai dengan peraturan perundangundangan.

\subsection{Dana Perimbangan}

Tujuan dari dana perimbangan termuat dalam PP No. 55 tahun 2005 Tentang Dana Perimbangan, dimana dana Perimbangan bertujuan untuk menciptakan keseimbangan keuangan antara Pemerintah Pusat dan Daerah dan antara Pemerintahan Daerah. Dana perimbangan terdiri dari Dana Bagi Hasil dari penerimaan pajak dan Sumber Daya Alam, Dana Alokasi Umum, dan Dana Alokasi Khusus.

\subsection{Dana Alokasi Umum}

Berdasarkan UU Nomor 33 Tahun 2004 menyatakan bahwa Dana Alokasi Umum (DAU) adalah dana yang bersumber dari pendapatan APBN yang dialokasikan dengan tujuan pemerataan kemampuan keuangan antar daerah untuk mendalami kebutuhan daerah dalam rangka pelaksanaan desentralisasi.

\subsection{Dana Alokasi Khusus}

Dana alokasi khusus merupakan salah satu komponen dari dana perimbangan yang dialokasikan pemerintah pusat kepada daerah tertentu untuk mendanai kegiatan khusus. Dalam Pasal 1 Undang-Undang Nomor 23 Tahun menyatakan bahwa Dana Alokasi Khusus (DAK) adalah dana yang bersumber dari pendapatan APBN yang dialokasikan kepada daerah tertentu untuk membantu mendanai kegiatan khusus yang merupakan urusan daerah dan sesuai dengan prioritas nasional.

\subsection{Dana Bagi Hasil}

Menurut UU No. 23 tahun 2014 Tentang Pemerintah Daerah, menyatakan bahwa dana bagi hasil adalah dana yang bersumber dari pendapatan tertentu APBN yang dialokasikan kepada Daerah penghasil berdasarkan angka persentase tertentu dengan tujuan mengurangi ketimpangan kemampuan keuangan antara Pemerintah Pusat dan Daerah.

\subsection{Pengembangan Hipotesis \\ Pengaruh Pendapatan Asli Daerah terhadap Belanja Daerah}

Pendapatan Asli Daerah (PAD) merupakan salah satu sumber pendapatan suatu daerah dari potensi-potensi yang dimiliki oleh daerah itu sendiri. Daerah yang berpotensi besar dari sumber daya alamnya serta ditunjang dengan sarana maupun prasarana yang memadai akan berpengaruh pada tingkat produktivitas masyarakatnya pada daerah tersebut yang pada akhirnya akan menambah Pendapatan Asli Daerah (PAD). Jika PAD suatu daerah meningkat, maka dana yang dimiliki oleh pemerintah daerah akan lebih tinggi sehingga Pemerintah Daerah akan berinisiatif untuk lebih menggali sumber potensi-potensi daerah. Hal ini menunjukan bahwa jika PAD suatu daerah meningkat, maka kemampuan daerah untuk melakukan pengeluaran belanja daerah pun akan ikut meningkat (Devita, dkk, 2014)

Penelitian sebelumnya tentang Pendapatan Asli Daerah yang berpengaruh signifikan terhadap Belanja Daerah telah dilakukan sebelumnya oleh Devita (2014), Saputri (2014), Liando (2017), Listiorini (2012), Nur (2015), Abdillah \& Mursinto (2016) dan Naganathan \& Sivagnanam (2000). Berdasarkan uraian tersebut, hipotesis penelitian seperti berikut ini: $\mathbf{H}_{1}$ : Pendapatan Asli Daerah berpengaruh signifikan terhadap Belanja Daerah 


\section{Pengaruh Dana Alokasi Umum terhadap Belanja Daerah}

Dana Alokasi Umum (DAU) merupakan salah satu sumber pendapatan penting bagi sebuah daerah. DAU menjadi jaminan kesinambungan penyelenggaraan Pemerintah Daerah di seluruh daerah dalam rangka penyediaan pelayanan dasar kepada masyarakat. Dana transfer ini akan menambah alokasi Belanja Daerah yang berguna untuk memenuhi segala pelayanan masyarakat serta pembangunan daerahnya. Terlebih lagi adanya tujuan untuk pemerataan dengan memperhatikan kondisi sekitar sehingga perbedaan antara daerah yang maju dengan daerah yang belum berkembang dapat diperkecil. Sehingga dengan ini Pemerintah Daerah akan memacu untuk terus mengembangkan daerahnya dengan menggunakan Belanja Daerah yang telah ditetapkan.

Penelitian sebelumnya tentang DAU yang berpengaruh signifikan terhadap Belanja Daerah telah dilakukan sebelumnya oleh Devita (2014), Saputri (2014), Liando (2014), Listiorini (2012), Laksono (2012), Yulina, dkk (2017) dan Nurlis (2016). Berdasarkan uraian tersebut, hipotesis penelitian seperti berikut ini:

$\mathbf{H}_{2}$ : Dana Alokasi Umum berpengaruh signifikan terhadap Belanja Daerah

\section{Pengaruh Dana Alokasi Khusus terhadap Belanja Daerah}

Dana Alokasi Khusus (DAK) yaitu dana yang diarahkan untuk membantu membiayai kegiatan-kegiatan khusus di daerah tertentu yang menjadi prioritas nasional, khususnya dalam membiayai pengadaan sarana dan prasarana pelayanan dasar masyarakat yang belum mencapai standar tertentu atau untuk mendorong percepatan pembangunan daerah. Sedangkan pengadaan sarana maupun prasarana ini merupakan salah satu urusan pemerintah daerah untuk memenuhi pelayanan terhadap masyarakat, dimana DAK ini juga menjadi dana transfer untuk memenuhi realisasi Belanja Daerah. Belanja Daerah yang menjadi sarana pembiayaan daerah juga berkesinambungan dengan DAK. Hal ini mencerminkan bahwa terdapat terdapat urusan pemerintah daerah yaitu terkait dengan pelayanan masyarakat menjadi prioritas nasional yang perlu didanai, maka dapat diproksikan bahwa Belanja Daerah juga akan ikut meningkat.

Penelitian sebelumnya tentang DAK yang berpengaruh signifikan terhadap Belanja Daerah telah dilakukan sebelumnya oleh Liando (2017), Nur (2015), Laksono (2014), Gani (2013), Hapid (2015). Berdasarkan uraian tersebut, hipotesis penelitian seperti berikut ini:

$\mathbf{H}_{3}$ : Dana Alokasi Khusus berpengaruh signifikan terhadap Belanja Daerah

\section{Pengaruh Dana Bagi Hasil terhadap Belanja Daerah}

Dana Bagi Hasil (DBH) merupakan salah satu sumber pendapatan daerah yang cukup potensial dan juga modal dasar pemerintah daerah dalam mendapatkan dana pembangunan dari pemerintah pusat serta memenuhi belanja daerah. Sasaran dan tujuan kegiatan pembangunan dan perekonomian daerah dalam rangka desentralisasi dapat diwujudkan dengan mengeluarkan belanja daerah dimana penerimaan dalam pengeluaran belanja ini dapat diterima dari DBH dan dikeluarkan dengan anggaran, alokasi hingga proporsi yang tepat. DBH yang diterima setiap daerah akan digunakan untuk membiayai pengeluaran, dimana belanja masuk diantara pengeluaran tersebut. Artinya jika penerimaan DBH yang diterima daerah meningkat maka Belanja Daerah pun akan ikut meningkat.

Penelitian sebelumnya tentang DBH yang berpengaruh signifikan terhadap Belanja Daerah telah dilakukan sebelumnya oleh Liando (2017), Yulina, dkk (2017) dan Hapid (2015). Berdasarkan uraian tersebut, hipotesis penelitian seperti berikut ini:

$\mathbf{H}_{4}$ : Dana Bagi Hasil berpengaruh signifikan terhadap Belanja Daerah

\section{METODE PENELITIAN}

\subsection{Pengukuran Variabel}

a. Variabel Dependen (Y)

Belanja Daerah diukur dengan menggunakan total Belanja Daerah yang diambil dari Laporan Operasional di Laporan Keuangan Pemerintah Daerah (LKPD). 
Belanja Daerah $=$ Ln Total Belanja Daerah

Belanja Daerah diproksikan menggunakan rumus Ln Total Belanja Daerah. Penggunaan natural $\log (\mathrm{Ln})$ dimaksudkan agar data penelitian yang memiliki perbedaan angka satuan dapat terdistribusi dengan normal. Skala data diukur menggunakan skala rasio.

b. Variabel Independen (X)

1) Pendapatan Asli Daerah (X1)

Pendapatan Asli Daerah diukur dengan menggunakan total Pendapatan Asli Daerah yang diambil dari Laporan operasional pada Laporan Keuangan Pemerintah Daerah (LKPD).

Pendapatan Asli Daerah = Ln Total Pendapatan Asli Daerah

Pendapatan Asli Daerah diproksikan menggunakan rumus Ln Total Pendapatan Asli Daerah. Penggunaan natural log (Ln) dimaksudkan agar data penelitian yang memiliki perbedaan angka satuan dapat terdistribusi dengan normal. Skala data diukur menggunakan skala rasio.

2) Dana Perimbangan

Pengukuran Dana Perimbangan dalam variabel ini diproksikan ke dalam variabel Dana

Alokasi Umum, Dana Alokasi Khusus, dan Dana Bagi Hasil.

a) Dana Alokasi Umum (X2)

Dana Alokasi Umum diukur dengan menggunakan total Dana Alokasi Umum yang diambil dari Laporan Operasional pada Laporan Keuangan pemerintah Daerah (LKPD).

Dana Alokasi Umum $=$ Ln Total Dana Alokasi Umum

Dana Alokasi Umum diproksikan menggunakan rumus Ln Total Dana Alokasi Umum. Penggunaan natural $\log (\mathrm{Ln})$ dimaksudkan agar data penelitian yang memiliki perbedaan angka satuan dapat terdistribusi dengan normal. Skala data diukur menggunakan skala rasio.

b) Dana Alokasi Khusus (X3)

Dana Alokasi Khusus diukur dengan menggunakan total Dana Alokasi Khusus yang diambil dari Laporan Operasional pada Laporan Keuangan pemerintah Daerah (LKPD).

Dana Alokasi Khusus = Ln Total Dana Alokasi Khusus

Dana Alokasi Khusus diproksikan menggunakan rumus Ln Total Dana Alokasi Khusus. Penggunaan natural log (Ln) dimaksudkan agar data penelitian yang memiliki perbedaan angka satuan dapat terdistribusi dengan normal. Skala data diukur menggunakan skala rasio.

c) Dana Bagi Hasil (X4)

Dana Alokasi Khusus diukur dengan menggunakan total Dana Alokasi Khusus yang diambil dari Laporan Operasional pada Laporan Keuangan pemerintah Daerah (LKPD).

Dana Alokasi Khusus = Ln Total Dana Alokasi Khusus

Dana Alokasi Khusus diproksikan menggunakan rumus Ln Total Dana Alokasi Khusus. Penggunaan natural $\log (\mathrm{Ln})$ dimaksudkan agar data penelitian yang memiliki perbedaan angka satuan dapat terdistribusi dengan normal. Skala data diukur menggunakan skala rasio.

\subsection{Metode Pengumpulan Data}

Jenis data yang digunakan dalam penelitian ini adalah data sekunder yang umumnya berupa bukti, catatan atau laporan historis tersusun dalam sebuah arsip (data dokumenter) yang telah dipublikasikan. Data sekunder yang digunakan dalam penelitian ini berasal dari data eksternal yaitu data LKPD yang telah diaudit dan dipublikasikan di Badan Pemeriksa Keuangan RI (BPK RI) periode 2015-2016. Pengumpulan data serta bahan-bahan dalam penelitian ini 
dilakukan melalui penelitian kepustakaan dan observasi pada LKPD yang diperoleh langsung dari BPK RI untuk memperoleh data laporan keuangan auditan.

\subsection{Teknik Analisis dan Uji Hipotesis}

Teknik analisis data yang digunakan dalam penelitian ini dilakukan dengan menggunakan menggunakan analisis regresi linier berganda yang dapat mengukur kekuatan hubungan antara dua variabel atau lebih, dengan dibantu program komputer yaitu SPSS 23 dan Microsoft Excel 2013 serta untuk membuktikan hipotesisi yang telah dibuat maka dilakukan uji hipotesis. Persamaan regresi linier berganda dalam penelitian ini adalah:

$$
\mathrm{Y}=\alpha+\beta_{1} \mathrm{X}_{1}+\beta_{2} \mathrm{X}_{2}+\beta_{3} \mathrm{X}_{3}+\beta_{4} \mathrm{X}_{4}+\varepsilon
$$

Keterangan :

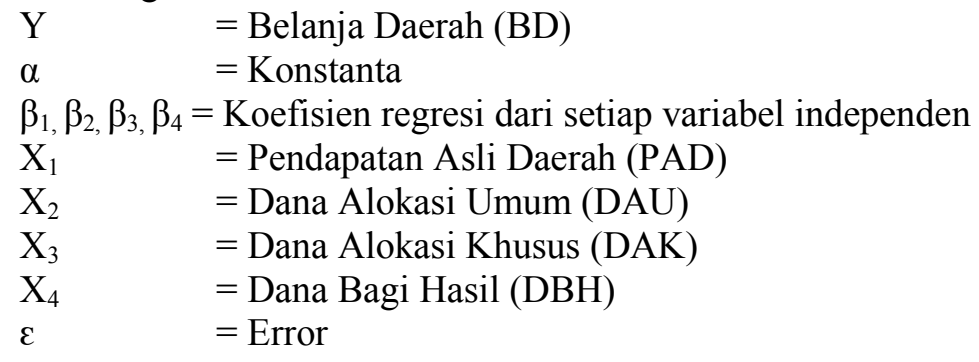

\section{HASIL DAN PEMBAHASAN}

\subsection{Analisis Statistik Deskriptif Induktif}

Analisis statistik deskriptif dilakukan agar dapat memberikan gambaran terhadap variabelvariabel yang digunakan dalam penelitian yang dilihat dari nilai minimum, maksimum, ratarata, dan standar deviasi (Ghozali, 2013, hlm. 19)

\begin{tabular}{lrrrrr} 
& $\begin{array}{c}\text { Hasil Uji Statistik Deskriptif } \\
\text { Tabel 1. Hasil Uji Statistik Deskriptif } \\
\text { Descriptive Statistics }\end{array}$ & \\
\hline & $N$ & Minimum & Maximum & Mean & $\begin{array}{c}\text { Std. } \\
\text { Deviation }\end{array}$ \\
\hline BD & 48 & 27,8568 & 28,5712 & 28,220298 &, 1911372 \\
\hline PAD & 48 & 25,4093 & 27,3004 & 26,195929 &, 4251528 \\
\hline DAU & 48 & 27,2953 & 27,9678 & 27,607833 &, 1404522 \\
\hline DAK & 48 & 24,8715 & 26,8917 & 25,889842 &, 6021949 \\
\hline DBH & 48 & 24,6952 & 25,7304 & 25,101727 &, 2555787 \\
\hline Valid N & 48 & & & & \\
(listwise) & 48 & & & & \\
\hline
\end{tabular}

Sumber: Data sekunder yang diolah

Dari tabel 1 di atas dapat dilihat secara keseluruhan bahwa variabel Belanja Daerah memiliki nilai terendah sebesar 27,8568 yang dimiliki oleh Kabupaten Situbondo pada tahun 2015 dan nilai tertinggi yaitu sebesar 28,5712 yang dimiliki oleh Kabupaten Banyuwangi pada tahun 2015. Rata-rata dari variabel Belanja Daerah yaitu sebesar 28,220298 dan standar deviasi sebesar 0,1911372 .

Nilai terendah variabel Pendapatan Asli Daerah sebesar 25,4093 yang dimiliki oleh Kabupaten Magetan pada tahun 2015 dan nilai tertinggi yaitu sebesar 27,3004 yang dimiliki 
oleh Kabupaten Gresik pada tahun 2016. Rata-rata dari variabel Pendapatan Asli Daerah yaitu sebesar 26,195929 dan standar deviasi sebesar 0,4251528.

Nilai terendah variabel Dana Alokasi Umum sebesar 27,2953 yang dimiliki oleh Kabupaten Pacitan pada tahun 2015 dan nilai tertinggi yaitu sebesar 27,9678 yang dimiliki oleh Kabupaten Banyuwangi pada tahun 2016. Rata-rata dari variabel Dana Alokasi Umum yaitu sebesar 27,607833 dan standar deviasi sebesar 0,1404522.

Nilai terendah variabel Dana Alokasi Khusus sebesar 24,8715 yang dimiliki oleh Kabupaten Jombang pada tahun 2015 dan nilai tertinggi yaitu sebesar 26,8917 yang dimiliki oleh Kabupaten Tulungagung pada tahun 2016. Rata-rata dari variabel Dana Alokasi Khusus yaitu sebesar 25,889842 dan standar deviasi sebesar 0,6021949.

Nilai terendah variabel Dana Bagi Hasil sebesar 24,6952 yang dimiliki oleh Kabupaten Trenggalek pada tahun 2015 dan nilai tertinggi yaitu sebesar 25,7304 yang dimiliki oleh Kabupaten Gresik pada tahun 2016. Rata-rata dari variabel Dana Bagi Hasil yaitu sebesar 25,101727 dan standar deviasi sebesar 0,2555787.

\subsection{Analisis Uji Asumsi Klasik Uji Normalitas}

a. Histogram

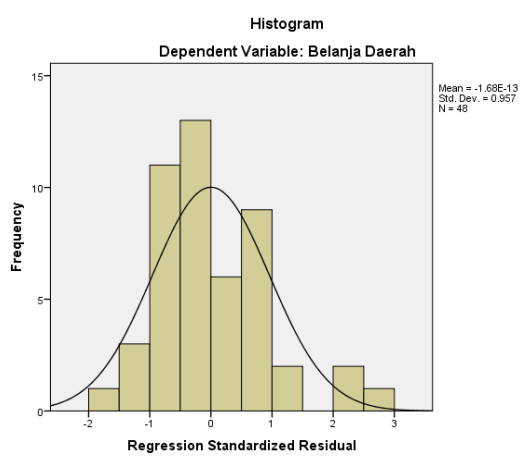

Sumber: Data sekunder yang diolah

Gambar 1. Hasil Uji Normalitas dengan Histogram

Hasil gambar di atas, kurva mengikuti bentuk bel (lonceng) dan tidak menceng ke kiri maupun ke kanan sehingga dapat dikatakan telah sesuai dengan dasar pengambilan keputusan. Hal ini menunjukkan pola distribusi secara normal, maka model regresi memenuhi asumsi normalitas.

b. P-plot

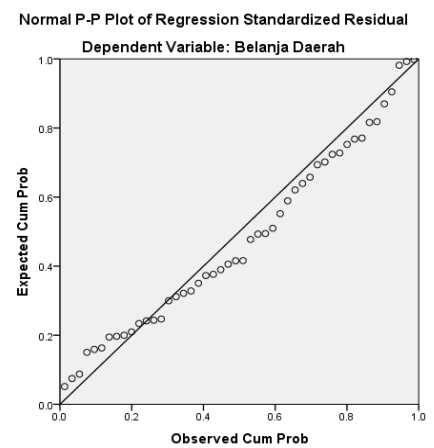

Sumber: Data sekunder yang diolah

Gambar 2. Hasil Uji Normalitas dengan P-Plot

Hasil dari gambar di atas, grafik P-plot diperoleh bahwa data mengikuti arah garis diagonal, maka dengan demikian model regresi memenuhi asumsi normalitas. 
Tabel 2. Hasil Uji Kolmogorov-Smirnov

One-Sample Kolmogorov-Smirnov Test

\begin{tabular}{|c|c|}
\hline & $\begin{array}{c}\text { Unstandardized } \\
\text { Residual }\end{array}$ \\
\hline$N$ & 48 \\
\hline Normal Mean &, 0000000 \\
\hline Parameters $^{a, b} \quad$ Std. Deviation & ,08155551 \\
\hline \multirow{2}{*}{$\begin{array}{l}\text { Most Extreme } \\
\text { Differences }\end{array}$} & 109 \\
\hline &, 109 \\
\hline Negative &,- 077 \\
\hline Test Statistic &, 109 \\
\hline Asymp. Sig. (2-tailed) & $200^{\mathrm{c}, \mathrm{d}}$ \\
\hline \multicolumn{2}{|l|}{$\begin{array}{l}\text { a. Test distribution is Normal. } \\
\text { b. Calculated from data. } \\
\text { c. Lilliefors Significance Correc }\end{array}$} \\
\hline
\end{tabular}

Sumber: Data sekunder yang diolah

Berdasarkan tabel di atas hasil uji Kolmogorov-Smirnov diketahui bahwa nilai Asymp. Sig adalah 0,200. Dapat dikatakan bahwa data terdistribusi normal dan memenuhi asumsi normalitas karena nilai yang diperoleh pada Asymp. Sig lebih besar dari 0,05 $(0,200>0,05)$.

\section{Uji Multikolinearitas}

Tabel 3. Hasil Uji Multikolonieritas

\begin{tabular}{llll}
\multicolumn{3}{c}{ Coefficients $^{\boldsymbol{a}}$} \\
\hline \multirow{3}{*}{ Model } & \multicolumn{3}{c}{$\begin{array}{c}\text { Collinearity } \\
\text { Statistics }\end{array}$} \\
\cline { 2 - 4 } & \multicolumn{2}{c}{ Tolerance } & VIF \\
\hline \multirow{2}{*}{1} & (Constant) &, 564 & 1,772 \\
\cline { 2 - 4 } & PAD &, 588 & 1,701 \\
\cline { 2 - 4 } & DAU &, 825 & 1,213 \\
\cline { 2 - 3 } & DAK &, 742 & 1,347 \\
\hline DBH &
\end{tabular}

a. Dependent Variable: Belanja Daerah

Sumber: Data sekunder yang diolahan

Berdasarkan hasil pengujian didapatkan bahwa nilai tolerance untuk masing-masing variabel bebas lebih besar dari 0,1 dan nilai VIF (Variance Inflation Factor) lebih kecil dari 10. Hal ini menunjukan bahwa variabel independen tidak terjadi gejala multikolinearitas.

\section{Uji Autokorelasi}

Tabel 4. Hasil Uji Autokorelasi

\section{Model Summary ${ }^{b}$}

\begin{tabular}{l}
$\frac{\text { Model Durbin-Watson }}{1,814}$ \\
\hline 1 a. Predictors: (Constant), DBH, \\
DAK, DAU, PAD \\
b. Dependent Variable: PAD
\end{tabular}

Sumber: Data sekunder yang diolah

Berdasarkan uji autokorelasi di atas, nilai Durbin-Waston sebesar 1,814, dimana $-2<\mathrm{DW}$ $<+2$ atau $-2<1,814<+2$, maka dapat disimpulkan bahwa model regresi ini tidak terdapat masalah autokorelasi. 


\section{Uji Heteroskedastisitas}

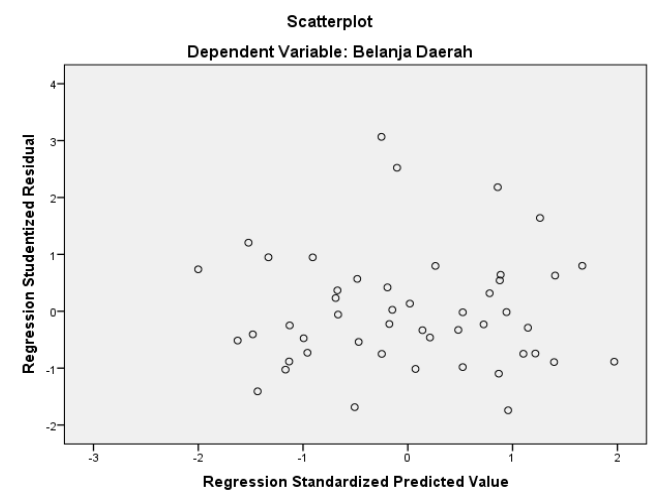

Sumber: Data sekunder yang diolah

Gambar 1. Hasil Uji Heteroskedastisitas Sesudah Outlier

Berdasarkan gambar di atas dapat dilihat bahwa titik-titik menyebar secara acak dan tidak membentuk sebuah pola tertentu yang jelas, serta tersebar baik diatas maupun dibawah angka 0 pada sumbu Y. Hal ini berarti menunjukkan bahwa tidak terjadi Heteroskedastisitas pada model regresi ini.

\begin{tabular}{lr}
\multicolumn{2}{c}{$\begin{array}{c}\text { Tabel 5. Hasil Uji Glejser } \\
\text { Coefficients }\end{array}$} \\
\hline \multicolumn{2}{c}{ Model } \\
\multicolumn{2}{c}{ Sig. } \\
\hline 1 & (Constant) \\
\cline { 2 - 2 } PAD &, 775 \\
\hline DAU &, 768 \\
\hline DAK &, 647 \\
\hline DBH &, 695 \\
\hline
\end{tabular}

a. Dependent Variable: Glejser 4

Sumber: Data sekunder yang diolah

Berdasarkan hasil pengujian didapatkan bahwa nilai signifikansi untuk masing-masing variabel bebas lebih besar dari 0,05 . Hal ini menunjukan bahwa tidak terjadi heteroskedastisitas pada model regresi dalam penelitian ini.

\subsection{Uji $\mathbf{R}^{2}$ (Koefisien Determinasi)}

Nilai koefisien determinasi yaitu antara nol dan satu, nilai yang digunakan adalah nilai adjusted $\mathrm{R}^{2}$. Nilai yang kecil berarti kemampuan variabel-variabel independen dalam menjelaskan variabel dependen amat terbatas.

Tabel 6. Hasil Uji Koefisien Determinasi

\begin{tabular}{lcrrr}
\multicolumn{4}{c}{ Model Summary $^{\boldsymbol{b}}$} \\
\hline Mode & \multicolumn{1}{c}{$R$} & Adjusted & Std. Error of \\
$l$ & $R$ & Square & $R$ Square & the Estimate \\
\hline 1 &, $904^{\mathrm{a}}$ &, 818 &, 801 &, 0852645 \\
\hline a. Predictors: & (Constant), DBH, DAK, DAU, \\
PAD & \\
b. Dependent Variable: BD \\
Sumber: Data sekunder yang diolah
\end{tabular}

EQUITY : Jurnal Ekonomi, Manajemen, Akuntansi | Vol. 21 No.1 
Berdasarkan pengujian di atas, menunjukan bahwa nilai Adjusted $R$ Square sebesar 0,801 atau sebesar $80,1 \%$. Hal ini menunjukkan bahwa presentase pengaruh variabel independen (Pendapatan Asli Daerah, Dana Alokasi Umum, Dana Alokasi Khusus, dan Dana Bagi Hasil) terhadap variabel dependen (Belanja Daerah) sebesar $80,1 \%$, sisanya 19,9\% dipengaruhi oleh variabel lain yang tidak dimasukkan dalam penelitian ini atau faktor-faktor lain yang terdiri dari Luas Wilayah, Jumlah Penduduk, dan Produk Domestik Regional Bruto.

\subsection{Uji t (Uji Parsial)}

Tabel 1. Hasil Uji Parsial

\begin{tabular}{llrr}
\multicolumn{4}{c}{ Coefficients $^{a}$} \\
\hline Model & \multicolumn{1}{c}{$t$} & \multicolumn{1}{c}{ Sig. } \\
\hline \multirow{2}{*}{1} & (Constant $)$ & 1,383 &, 174 \\
\cline { 2 - 3 } & PAD & 6,115 &, 000 \\
\hline DAU & 5,839 &, 000 \\
\hline DAK &,- 745 &, 461 \\
\hline DBH &, 002 &, 999 \\
\hline
\end{tabular}

a. Dependent Variable: Belanja Daerah

Sumber: Data sekunder yang diolah

Untuk mencari $\mathrm{t}_{\text {tabel }}$ menggunakan rumus $\mathrm{df}=\mathrm{n}-\mathrm{k}-1$ dimana $\mathrm{n}=$ jumlah sampel dan $\mathrm{k}=$ jumlah variabel independen, sehingga di dapat $\mathrm{df}=48-4-1=43$, dengan menggunakan taraf signifikansi 0,05 diperoleh $\mathrm{t}_{\text {tabel }}$ sebesar 2,01669.

Berdasarkan tabel 23 uji t (Uji Parsial) dapat diketahui bahwa variabel Pendapatan Asli Daerah memiliki $t_{\text {hitung }}$ sebesar 6,115 sedangkan $t_{\text {tabel }}$ sebesar 2,01669 dan nilai $t_{\text {hitung }}>t_{\text {tabel }}$ dengan signifikansi $0,000<0,05$. Hal ini menunjukkan bahwa $\mathrm{H}_{\mathrm{o} 1}$ ditolak dan $\mathrm{H}_{\mathrm{a} 1}$ diterima, sehingga dapat disimpulkan bahwa Pendapatan Asli Daerah berpengaruh signifikan terhadap Belanja Daerah. Artinya, dengan peningkatan Pendapatan Asli Daerah, sejalan dengan meningkatnya jumlah Belanja Daerah.

Berdasarkan tabel uji t (Uji Parsial) dapat diketahui bahwa variabel Dana Alokasi Umum memiliki $t_{\text {hitung }}$ sebesar 5,839 sedangkan $t_{\text {tabel }}$ sebesar 2,01669 dan nilai $t_{\text {hitung }}>t_{\text {tabel }}$ dengan signifikansi $0,000<0,05$. Hal ini menunjukkan bahwa $\mathrm{H}_{\mathrm{o} 2}$ ditolak dan $\mathrm{H}_{\mathrm{a} 2}$ diterima, sehingga dapat disimpulkan bahwa Dana Alokasi Umum berpengaruh signifikan terhadap Belanja Daerah. Artinya, dengan peningkatan Dana Alokasi Umum, sejalan dengan meningkatnya jumlah Belanja Daerah.

Berdasarkan tabel uji t (Uji Parsial) dapat diketahui bahwa variabel Dana Alokasi Khusus memiliki $t_{\text {hitung }}$ sebesar -0,745 sedangkan $t_{\text {tabel }}$ sebesar 2,01669 dan nilai $t_{\text {hitung }}<t_{\text {tabel }}$ dengan signifikansi 0,461 >0,05. Hal ini menunjukkan bahwa $\mathrm{H}_{03}$ diterima dan $\mathrm{H}_{\mathrm{a} 3}$ ditolak, sehingga dapat disimpulkan bahwa Dana Alokasi Khusus berpengaruh tidak signifikan terhadap Belanja Daerah.

Berdasarkan tabel uji t (Uji Parsial) dapat diketahui bahwa variabel Dana Bagi Hasil memiliki $t_{\text {hitung }}$ sebesar 0,002 sedangkan $t_{\text {tabel }}$ sebesar 2,01669 dan nilai $t_{\text {hitung }}<t_{\text {tabel }}$ dengan signifikansi 0,999 >0,05. Hal ini menunjukkan bahwa $\mathrm{H}_{\mathrm{o} 4}$ diterima dan $\mathrm{H}_{\mathrm{a} 4}$ ditolak, sehingga dapat disimpulkan bahwa Dana Bagi Hasil berpengaruh tidak signifikan terhadap Belanja Daerah. 


\subsection{Model Regresi Berganda}

Tabel 2. Hasil Uji Regresi Linear Berganda

\begin{tabular}{|c|c|c|c|}
\hline \multicolumn{4}{|c|}{ Coefficients $^{a}$} \\
\hline \multirow[t]{2}{*}{ Model } & $\begin{array}{r}\text { Unstan } \\
\text { Coeff }\end{array}$ & $\begin{array}{l}\text { ardized } \\
\text { cients }\end{array}$ & $\begin{array}{c}\text { Standardized } \\
\text { Coefficients }\end{array}$ \\
\hline & $B$ & $\begin{array}{l}\text { Std. } \\
\text { Error }\end{array}$ & Beta \\
\hline 1 (Constant $)$ & 3,803 & 2,750 & \\
\hline Pendapatan Asli Daerah & 238 &, 039 &, 530 \\
\hline Dana Alokasi Umum & ,674 & ,115 & ,495 \\
\hline Dana Alokasi Khusus &,- 017 &, 023 &,- 053 \\
\hline Dana Bagi Hasil &,- 009 & 056 & 000 \\
\hline
\end{tabular}

a. Dependent Variable: Belanja Daerah

Sumber: Data sekunder yang diolah

Berdasarkan tabel 24 di atas, maka diperoleh persamaan regresi sebagai berikut:

$$
\text { Belanja Daerah }=3,803+0,238 \mathrm{PAD}+0,674 \mathrm{DAU}-0,017 \mathrm{DAK}-0,009 \mathrm{DBH}
$$

Berdasarkan rumus regresi linier berganda di atas dapat diketahui bahwa nilai konstanta sebesar 3,803. Hal ini menunjukan bahwa jika variabel independen yaitu Pendapatan Asli Daerah, Dana Alokasi Umum, Dana Alokasi Khusus, dan Dana Bagi Hasil dianggap konstan atau 0, maka Belanja Daerah nilainya sebesar 3,803. Artinya, berdasarkan pengujian atas sampel penelitian, dengan asumsi bahwa seluruh nilai variabel independen adalah 0 , maka besarnya Belanja Daerah Kabupaten dan Kota di Jawa Timur yaitu sebesar 3,803.

Variabel Pendapatan Asli Daerah memiliki koefisien regresi sebesar 0,238 menyatakan bahwa jika setiap peningkatan satu satuan Pendapatan Asli Daerah dengan asumsi nilai koefisien variabel lain tetap, maka hal tersebut akan menaikkan nilai Belanja Daerah sebesar 0,238 .

Variabel Dana Alokasi Umum memiliki koefisien regresi sebesar 0,674 menyatakan bahwa jika setiap peningkatan satu satuan Dana Alokasi Umum dengan asumsi nilai koefisien variabel lain tetap, maka hal tersebut akan menaikkan nilai Belanja Daerah sebesar 0,674.

Variabel Dana Alokasi Khusus memiliki koefisien regresi sebesar -0,017 menyatakan bahwa jika setiap peningkatan satu satuan Dana Alokasi Khusus dengan asumsi nilai koefisien variabel lain tetap, maka hal tersebut akan menaikkan nilai Belanja Daerah sebesar -0,017.

Variabel Dana Bagi Hasil memiliki koefisien regresi sebesar -0,009 menyatakan bahwa jika setiap peningkatan satu satuan Dana Bagi Hasil dengan asumsi nilai koefisien variabel lain tetap, maka hal tersebut akan menurunkan nilai Belanja Daerah sebesar -0,009.

\subsection{PEMBAHASAN}

\section{Pengaruh Pendapatan Asli Daerah terhadap Belanja Daerah}

Hipotesis pertama menunjukan bahwa Pendapatan Asli Daerah berpengaruh signifikan terhadap Belanja Daerah. Hal tersebut dapat dilihat dari hasil uji hipotesis dimana nilai Pendapatan Asli Daerah sebesar 0,000. Yang berarti hipotesis pertama pertama ditolak yang menyatakan bahwa Pendapatan Asli Daerah berpengaruh terhadap Belanja Daerah. Hal ini sejalan dengan hasil penelitian sebelumnya yang dilakukan oleh Devita (2014), Saputri (2014), Liando (2017), Listiorini (2012), Nur (2015), Abdillah \& Mursinto (2016) dan Naganathan \& Sivagnanam (2000), Yulina, dkk (2017) dan Nurlis (2016) yang menyatakan bahwa Pendapatan Asli Daerah berpengaruh signifikan terhadap Belanja Daerah. Namun 
penelitian ini tidak sejalan dengan penelitian sebelumnya yang dilakukan oleh Sorongan (2013) dan Sasana (2011) yang menunjukan bahwa pendapatan asli daerah tidak berpengaruh signifikan terhadap belanja daerah.

Hal penelitian ini tercermin pada salah satu data sampel yaitu Kabupaten Jombang pada tahun 2015 dan 2016 masing-masingnya yaitu sebesar Rp. 355.794.521.732,96 dan Rp. 393.179.369.812,71 dimana jumlah keduanya melampaui nilai rata-rata Pendapatan Asli Daerah yaitu sebesar Rp. 261.076.852.490,37 serta hal tersebut diikuti dengan meningkatnya Belanja Daerah pada kedua tahun tersebut yaitu sebesar Rp. 1.917.622.378.687,16 dan Rp. 2.146.035.591.839,87.

\section{Pengaruh Dana Alokasi Umum terhadap Belanja Daerah}

Hipotesis kedua menunjukan bahwa Dana Alokasi Umum berpengaruh signifikan terhadap Belanja Daerah. Hal tersebut dapat dilihat dari hasil uji hipotesis dimana nilai Dana Alokasi Umum sebesar 0,000. Yang berarti hipotesis pertama pertama ditolak yang menyatakan bahwa Dana Alokasi Umum berpengaruh terhadap Belanja Daerah. Hal ini sejalan dengan penelitian sebelumnya yang dilakukan oleh Devita (2014), Saputri (2014), Liando (2014), Listiorini (2012), Laksono (2012), Gani (2013), Hapid (2015), Abdillah \& Mursinto (2016), Yulina, dkk (2017) dan Nurlis (2016) yang menyatakan bahwa Dana Alokasi Umum berpengaruh signifikan terhadap Belanja Daerah. Namun hasil penelitian ini berbanding terbalik dengan penelitian sebelumnya yang dilakukan oleh Sorongan (2013) dan Nur (2015) menunjukan bahwa dana alokasi umum tidak berpengaruh signifikan terhadap belanja daerah.

Hasil penelitian ini tercermin pada salah satu sampel yaitu Kabupaten Sumenep pada tahun 2015 dan 2016 masing-masingnya yaitu sebesar Rp. 1.010.159.421.000,00 dan Rp. 1.110.487.853.000,00 dimana jumlah keduanya melampaui nilai rata-rata Dana Alokasi Umum yaitu sebesar Rp. 986.651.484.057,96 serta diikuti dengan meningkatnya Belanja Daerah pada masing-masing tahun tersebut yaitu sebesar Rp. 1.731.456.088.064,03 dan Rp. 2.007.976.748.073,92.

\section{Pengaruh Dana Alokasi Khusus terhadap Belanja Daerah}

Hipotesis ketiga menunjukan bahwa Dana Alokasi Khusus berpengaruh signifikan terhadap Belanja Daerah. Hal tersebut dapat dilihat dari hasil uji hipotesis dimana nilai Pendapatan Asli Daerah sebesar 0,000. Yang berarti hipotesis pertama pertama ditolak yang menyatakan bahwa Pendapatan Asli Daerah berpengaruh terhadap Belanja Daerah. Hal ini sejalan dengan penelitian sebelumnya yang dilakukan oleh Handayani (2012) dan Listiorini (2012) yang menunjukan bahwa Dana Alokasi Khusus tidak berpengaruh signifikan terhadap Belanja Daerah. Namun penelitian ini tidak sejalan dengan penelitian sebelumnya yang dilakukan oleh Liando (2017), Nur (2015), Laksono (2014), Gani (2013), Hapid (2015), Abdillah \& Mursinto (2016), dan Yulina, dkk (2017) yang menyatakan bahwa Dana Alokasi Khusus berpengaruh signifikan terhadap Belanja Daerah.

Hasil penelitian ini tercermin pada salah satu sampel yaitu Kabupaten Pamekasan pada tahun 2015 dan 2016 masing-masingnya yaitu sebesar Rp. 143.369.090.000,00 dan Rp. 346.060.851.131,00 dimana jumlah pada tahun 2015 tidak mencapai nilai rata-rata namun ditahun selanjutnya Kabupaten Pamekasan telah melampaui nilai rata-rata Dana Alokasi Khusus yaitu sebesar Rp. 206.881.848.787,48. Hal ini juga tidak sesuai dengan realisasi Belanja Daerah Kabupaten Pamekasan pada tahun 2015 mencapai Rp. 1.453.567.909.390,98, lalu pada tahun selanjutnya realisasi Belanja Daerah justru mengalami penurunan menjadi sebesar Rp. 1.439.551.521.018,10. 


\section{Pengaruh Dana Bagi Hasil terhadap Belanja Daerah}

Hasil uji t (parsial) terkait variabel Dana Bagi Hasil terhadap Belanja Daerah seluruh Kabupaten dan Kota di Provinsi Jawa Timur pada tahun 2015-2016 dengan tingkat signifikansi untuk variabel Dana Bagi Hasil dengan hasil 0,999>0,05, yang menunjukkan bahwa variabel Dana Bagi Hasil berpengaruh tidak signifikan terhadap Belanja Daerah. Hal ini sejalan dengan penelitian sebelumnya yang dilakukan oleh Listiorini (2012) dan Abdillah \& Mursinto (2016) menunjukan bahwa Dana Bagi Hasil tidak berpengaruh terhadap belanja daerah. Namun hasil penelitian ini tidak sejalan dengan penelitian yang dilakukan oleh Liando (2017), Yulina, dkk (2017) dan Hapid (2015) yang menunjukan bahwa Dana Bagi Hasil berpengaruh siginifikan terhadap belanja daerah.

Hasil penelitian ini tercermin pada salah satu sampel yaitu Kabupaten Bangkalan pada tahun 2015 dan 2016 masing-masingnya yaitu sebesar Rp. 94.556.538.627,00 dan Rp. 70.645.441.065,00 dimana jumlah dari tahun tersebut mengalami penurunan hingga dibawah dari nilai rata-rata Dana Bagi Hasil yaitu sebesar Rp. 82.450.809.754,92. Hal ini juga tidak sesuai dengan realisasi Belanja Daerah Kota Malang pada tahun 2015 mencapai Rp. 1.631.371.947.684,48, lalu pada tahun selanjutnya realisasi Belanja Daerah justru mengalami penurunan menjadi sebesar Rp. 2.226.577.839.969,79.

\section{SIMPULAN, KETERBATASAN, DAN SARAN}

\subsection{Simpulan}

a. Hasil penelitian menunjukkan bahwa Pendapatan Asli Daerah berpengaruh signifikan terhadap Belanja Daerah.

b. Hasil penelitian menunjukkan bahwa Dana Alokasi Umum berpengaruh signifikan terhadap Belanja Daerah.

c. Hasil penelitian menunjukkan bahwa Dana Alokasi Khusus berpengaruh tidak signifikan terhadap Belanja Daerah.

d. Hasil penelitian menunjukkan bahwa Dana Bagi Hasil berpengaruh tidak signifikan terhadap Belanja Daerah.

\subsection{Keterbatasan}

a. Pada penelitian ini terdapat beberapa nilai data yang terlalu ekstrem, sehingga hal tersebut menyulitkan peneliti untuk mengolah data penelitian

b. Ada beberapa daerah yang Laporan Hasil Pemeriksaan atas Laporan Keuangan Pemerintah Daerah disajikan dalam bentuk scan yang hasilnya tidak mudah untuk dibaca sehingga untuk melihat Laporan Realisasi Anggaran yang digunakan dalam penelitian ini harus memeriksa Catatan Atas Laporan Keuangan terlebih dahulu.

\subsection{Saran}

a. Peneliti selanjutnya di sarankan dapat melakukan penelitian dengan penambahan variabel independen yang berbeda dalam mempengaruhi Belanja Daerah dan dapat melakukan penelitian dengan data atau sampel dalam rentang waktu yang lebih panjang serta populasi yang lebih luas.

b. Pemerintah daerah disarankan lebih mampu untuk mengelola Belanja Daerah dengan baik lagi sehingga penyerapan Belanja Daerah dapat direalisasikan secara optimal lagi ke depannya. Dimana realisasi Belanja Daerah dalam bentuk pengadaan pelayanan masyarakat sangatlah dibutuhkan bagi masyarakat. 


\section{DAFTAR PUSTAKA}

, Undang-Undang Republik Indonesia No. 17 Tahun 2003 Tentang Keuangan Daerah. (2003). Jakarta.

, Undang-Undang Republik Indonesia Nomor 23 Tahun 2014 Tentang Pemerintah Daerah. (2014). Jakarta.

, Undang-Undang Republik Indonesia Nomor 25 Tahun 1999 tentang Perimbangan Keuangan antara Pemerintah Pusat dan Daerah. (1999). Jakarta.

, Undang-Undang Republik Indonesia Nomor 28 Tahun 2009 Tentang Pajak Daerah dan Retribusi Daerah. (2009). Jakarta.

, Undang-Undang Republik Indonesia Nomor 32 Tahun 2004 Tentang Pemerintah Daerah. (2004). Jakarta.

, Undang-Undang Republik Indonesia Nomor 33 Tahun 2004 Tentang Perimbangan Keuangan antara Pemerintah Pusat dan Daerah. (2004). Jakarta.

, Undang-Undang Republik Indonesia Nomor 52 Tahun 2009 Tentang Perkembangan Kependudukan dan Pembangunan Keluarga. (2009). Jakarta.

, Peraturan Pemerintah Republik Indonesia Nomor 55 Tahun 2005 Tentang Dana Perimbangan. (2005). Jakarta.

, Peraturan Pemerintah Republik Indonesia Nomor 58 Tahun 2005 Tentang Pengelolaan Keuangan Daerah. (2005). Jakarta.

, Peraturan Pemerintah Republik Indonesia Nomor 71 Tahun 2010 tentang Standar Akuntansi Pemerintah. (2010). Jakarta.

, Peraturan Menteri Dalam Negeri Nomor 13 Tahun 2006 Tentang Pedoman Pengelolaan Keuangan Daerah. (2006). Jakarta.

, Peraturan Menteri Dalam Negeri Nomor 64 Tahun 2013 Tentang Penerapan Standar Akuntansi Pemerintahan Berbasis Akrual pada Pemerintah Daerah. (2013). Jakarta.

Abdillah, Khubbi, and Mursinto, Djoko. (2016). The Effects of Financial Balance Transfer and Regional Own-Source Revenue on Regional Expenditure of Regencies and Municipalities in East Java Province, International Journal Of Advanced Research, Volume 6, Issue 5, 26-20

Bawono, I. R., \& Novelsyah, M. (2012). Tata cara penatausahaan dan pertanggungjawaban bendahara pada SKPD dan SKPKD, Salemba Empat.

Erlina, Rambe, O.S., dan Rasdianto. (2015). Akuntansi Keuangan Daerah Berbasis Akrual Berdasarkan PP.No. 71 Tahun 2010 dan Permendagri No. 64 tahun 2013, Jakarta: Salemba Empat. 
Devita, A., Delis, A., \& Junaidi, J. (2014). Pengaruh Pendapatan Asli Daerah, Dana Alokasi Umum dan Jumlah Penduduk terhadap Belanja Daerah Kabupaten/Kota di Provinsi Jambi, Jurnal Perspektif Pembiayaan dan Pembangunan Daerah, 2(2), 63-70.

Gani, W., \& Kristanto, S. B. (2013). Pengaruh Dana Alokasi Umum Dan Khusus terhadap Belanja Daerah Pada Kabupaten/Kota Di Pulau Sumatera, InFestasi, 9(2), 115-122.

Ghozali, I., (2016). Aplikasi Analisis Multivariete Dengan Program IBM SPSS 23, Badan Penerbit Universitas Diponegoro, Semarang.

Hadi, N. (2014). Corporate Social Responsibility. Yogyakarta: Graha Ilmu.

Halim, Abdul 2016. Manajemen Keuangan Sektor Publik. Jakarta: Salemba Empat.

Halim, A. \& Kusufi, M.S. (2012). Akuntansi Keuangan Daerah. Edisi 4, Salemba Empat.

Hamdani, (2016). Good Corporate Governance: Tinjauan Etika Dalam Praktik Bisnis, Mitra Wacana Media, Jakarta.

Handayani, D., \& Nuraina, E. (2012). Pengaruh Pajak Daerah dan Dana Alokasi Khusus Terhadap Alokasi Belanja Daerah Kabupaten Madiun, Assets: Jurnal Akuntansi dan Pendidikan, 1(1), 1-12.

Hapid, H., Halim, M., \& Wulandari, Y. (2016). Pengaruh Dana Alokasi Khusus, Dana Bagi Hasil Dan Dana Alokasi Umum Terhadap Anggaran Pendapatan Dan Belanja Daerah Kabupaten Luwu, Jurnal Ekonomi Pembangunan, 2(1).

Harahap. (2012). Teori akuntansi, Jakarta: Rajawali Pers.

Lako, A. (2011). Dekonstruksi CSR \& Reformasi Paradigma Bisnis \& Akuntansi, Jakarta: Penerbit Erlangga.

Laksono, B. B., \& Subowo, S. (2014). Pengaruh Pajak Daerah, Retribusi Daerah, Dau Dan Dak Terhadap Belanja Daerah, Accounting Analysis Journal, 3(4).

Liando, I. I., \& Hermanto, S. B. (2017). Faktor-Faktor Yang Mempengaruhi Belanja Daerah Pada Kabupaten/Kota Jawa Timur, Jurnal Ilmu dan Riset Akuntansi, 6(6).

Listiorini, L. (2012). Fenomena Fly Paper Effect Pada Dana Perimbangan Dan Pendapatan Asli Daerah Terhadap Belanja Daerah Pada Kabupaten/Kota Di Sumatera Utara, Jurnal Keuangan \& Bisnis Program Studi Magister Manajemen Sekolah Tinggi Ilmu Ekonomi Harapan, 4(2), 111-126.

Lontaan, I. C., \& Pangerapan, S. (2016). Analisis Belanja Daerah Pada Pemerintah Kabupaten Minahasa Tahun Anggaran 2012-2014, Jurnal EMBA: Jurnal Riset Ekonomi, Manajemen, Bisnis dan Akuntansi, 4(1).

Mahmudi. (2010). Manajemen Keuangan Daerah. Erlangga.

Masdjojo, G. N. Sukartono. 2009. Pengaruh Pendapatan Asli Daerah dan Dana Perimbangan terhadap Belanja Daerah Serta Analisis Flypaper Effect Kabupaten/kota di Jawa Tengah Tahun 2006-2008. Jurnal Telaah Manajemen, 6(1). 
Naganathan, M \& Sivagnanam, J.K. (2000). Federal transfer and the tax effort of the states in India. Indian Economic Journal. Vol. 47 No. 04. University of Madras. hlm 252-281.

Nordiawan, dkk. (2012). Akuntansi Pemerintahan, Jakarta: Salemba Empat.

Nur, M. (2015). Pengaruh Pendapatan Asli Daerah, Dana Alokasi Umum, dan Dana Alokasi Khusus terhadap Belanja Daerah di Sulawesi Selatan. In Assets. Vol. 5, No. 1.

Nurlis. (2016). The Factors Affecting of the Capital Expenditure Allocation Case: The Local Government of Indonesia. Research Journal of Finance and Accounting. ISSN 22222847. Vol. 7, No. 1. Hal. 107-113.

Rusdianto, U., (2013). CSR Communication A Framework For PR Practitioners, Graha Ilmu, Yogyakarta.

Saputri, M. A., \& Muid, D. (2014). Flypaper Effect Pada Dana Alokasi Umum Dan Pendapatan Asli Daerah Terhadap Belanja Daerah Pada Kabupaten/Kota Di Jawa Tengah Tahun 2011-2012. Diponegoro Journal of Accounting, 3(2), 747-757.

Sarwono, Jonathan. (2015). Rumus-Rumus Populer Dalam SPSS 22 Untuk Riset Skripsi, C.V ANDI OFFSET, Yogyakarta.

Sasana, H. (2011). Analisis Determinan Belanja Daerah di Kabupaten/Kota Provinsi Jawa Barat dalam era otonomi dan Desentralisasi Fiskal. Jurnal Bisnis dan Ekonomi, 18(1).

Sekaran, U. (2006). Research Methods For Business, Edisi 4, Jakarta: Salemba Empat.

Sesung, R. (2013). Hukum Otonomi Daerah: Negara Kesatuan, Daerah Istimewa, Dan Daerah Otonomi Khusus. Bandung: Refika Aditama.

Soleh, A. (2015). Analisis Belanja Pemerintah Daerah Kota Bengkulu. Ekombis Review, 3(1).

Sorongan, J. F. (2013). Analisis Hubungan DAU, PAD dan Belanja Daerah di Kabupaten Minahasa Selatan. Jurnal EMBA: Jurnal Riset Ekonomi, Manajemen, Bisnis dan Akuntansi, 1(3).

Suwardjono. (2010). Teori Akuntansi: Perekayasaan Pelaporan Keuangan, Edisi Ketiga. Yogyakarta: BPFE-Yogyakarta.

Yulina, B. (2017). Fenomena Flypaper Effect Pada Dana Perimbangan Dan Pendapatan Asli Daerah Pemerintah Kabupaten/Kota Di Sumatera Selatan. Jurnal Riset Terapan Akuntansi Polsri, 1(2). 